\title{
Multiple Drug-resistant Plasmids from Edwardsiella tarda in Eel Culture Ponds
}

\author{
Takashi Aoki,* Tetsumi Sakaguchi,* and Tadatoshi Kitao*
}

(Accepted March 9, 1987)

\begin{abstract}
One hundred fifty-two strains of 186 strains of Edwardsiella tarda collected from eel culture ponds in various areas in Japan in 1983 and 1984 showed resistance to one or a combination of the following drugs; chloramphenicol (CP), tetracycline (TC), streptomycin (SM), nalidixic acid (NA), furazolidone (NF), and/or sulfonamide (SA). Strains resistant to NA and NF were detected at high frequency. Transferable $\mathbf{R}$ plasmids were detected in 31 of the 152 resistant strains. $\mathbf{R}$ plasmids encoding for resistance to $\mathrm{CP}, \mathrm{TC}$, and $\mathrm{SA}$ were predominant. Other $\mathrm{R}$ plasmids encoded for resistance to TC, SA; CP, SA; and CP, TC, SM, and SA. The HindIII or Pst I digestion patterns of the $R$ plasmids with different resistant markers were similar except one $R$ plasmid with resistance to CP, TC, SM, and SA. Southern blot hybridization ${ }^{1)}$ showed these $\mathbf{R}$ plasmids to have high homology with $\mathrm{pK} 4$, a typical R plasmid from $E$. tarda detected in the $1970^{\text {'s. }}{ }^{2}$ ) Therefore, drug resistant strains of $E$. tarda carrying $\mathbf{R}$ plasmids with the same DNA structure have prevailed in Japanese eel culture ponds since 1972.
\end{abstract}

In Japan, eels are widely cultured in green houses utilizing oil-heated warm water. Edwardsiella septicemia caused by Edwardsiella tarda occurs frequently in various sizes of young and adult eels throughout the year. Attempts to control this and other bacterial infections are made through the application of chemotherapeutic agents to the cultured eels. This practice has caused an increased incidence of drug resistant bacteria. We previously reported that drugresistant strains of $E$. tarda carrying transferable $\mathrm{R}$ plasmid have appeared at high frequency in cultured eel. ${ }^{3,4)}$ The properties and DNA structure of the transferable $\mathrm{R}$ plasmids from $E$. tarda, which were isolated from various areas during 1972 to 1979 , were characterized. The $\mathbf{R}$ plasmids from $E$. tarda were closely related and had similar base sequences. ${ }^{2)}$ Outbreaks of disease caused by multiple drug-resistant $E$. tarda have been prevalent in eel ponds in the 1980's. Therefore, epidemiological surveillance of drugresistant $E$. tarda strains is important for the treatment of edwardsiellosis in cultured eels.

In the present study, we surveyed strains of $E$. tarda carrying $\mathbf{R}$ plasmids. The multiple drugresistant bacteria were isolated from culture eels in 1983 and 1984. Southern bolt hybridization analysis $^{1)}$ was used to study the relationship of the detected $\mathbf{R}$ plasmids.

\section{Materials and Methods}

\section{Bacterial Strains and Plasmids}

One-hundred eighty-six strains of E. tarda were collected from eel with edwardsiella septicemia in various areas of Japan between 1983 and 1984 (Table 1). Escherichia coli K-12 RC85 met, nal, $\mathrm{F}^{-},{ }^{5)} \mathrm{HB} 101$ recA $A^{-}, \mathrm{r}^{-}, \mathrm{m}^{-}$, ara, proA, lacY, galK, str ${ }^{r}$, mtl, SupE ${ }^{\left.,{ }^{8}\right)} \mathrm{W} 677 \mathrm{thr}$, leu, thi, pro, man, $x y l, m a l, g a l, l a c, s t r^{\tau}, t s x^{\tau}, F^{-7)}$ and C600 thi, $t h r, \operatorname{leuB}, \operatorname{lac} Y, \operatorname{ton} A, \operatorname{Sup} E$, rif $^{\gamma}, F^{-8)}$ were used as recipients for the transferable $R$ plasmids. The DNA structure of transferable $R$ plasmids selected at random from various geographical areas was compared. The $\mathrm{R}$ plasmid, $\mathrm{pK} 4^{2}$ ) detected in an E. tarda strain isolated in 1978, was used as the basis for the comparisons (Table 2). The standard molecular size marker was $2 D N A$ digested by HindIII.

\section{Growth Media}

Strains of $E$. tarda were isolated on nutrient agar $(5 \mathrm{~g}$ beef extract, $10 \mathrm{~g}$ polypeptone and $5 \mathrm{~g}$ $\mathrm{NaCl}$ per liter) and subcultured at $37^{\circ} \mathrm{C}$ in Heart infusion (HI) broth (Nissui). A drug sensitivity disc medium (Nissui) was used to test the suscep-

* Department of Fisheries, Faculty of Agriculture, Miyazaki University, Kumano, Miyazaki 889-21, Japan (青木 宙, 坂口哲美, 北尾忠利: 宫第大学農学部水産增殖学科). 


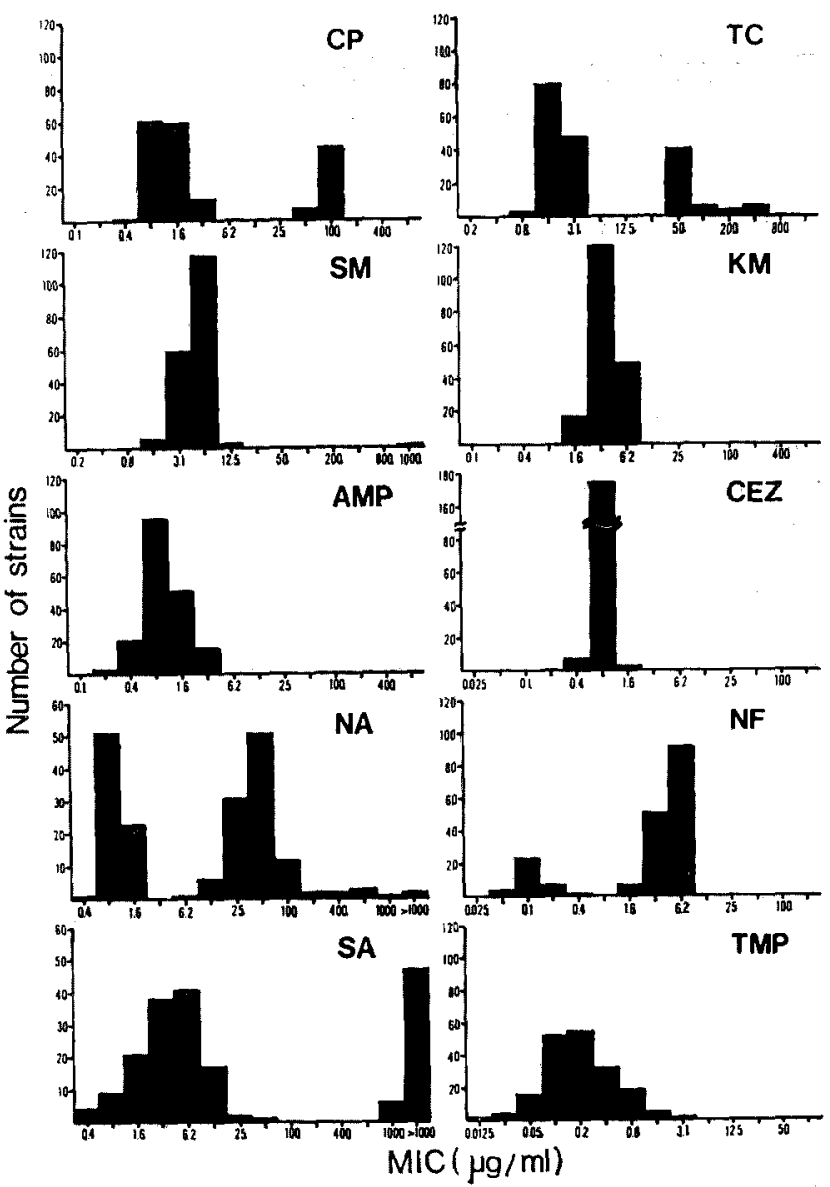

Fig. 1. Minimal inhibitory concentrations of 10 chemotherapeutics for 186 strains of Edwardsiella tarda.

Abbreviations: CP, chloramphenicol; TC, tetracycline; SM, streptomycin; KM, kanamycin; AMP, ampicillin; CEZ, cephazolin; NA, nalidixic acid; NF, furazolidone; SA, sulfamonomethoxine; and TMP, trimethoprim.

Table 1. Sources of strains of Edwardsiella tarda

\begin{tabular}{lrrr}
\hline \multirow{2}{*}{ Area } & \multicolumn{2}{c}{ Year } & Total \\
\cline { 2 - 3 } & 1983 & 1984 & \\
\hline Shizuoka & & $33^{*}$ & 33 \\
Aichi & 36 & 73 & 109 \\
Tokushima & & 4 & 4 \\
Nagasaki & 10 & 8 & 18 \\
Saga & 2 & 2 & 4 \\
Oita & 1 & & 1 \\
Miyazaki & 1 & 3 & 4 \\
Kagoshima & & 13 & 13 \\
Total & 50 & 136 & 186 \\
\hline
\end{tabular}

* Number of strains.

tibility of the strains to sulfamonomethoxine (SA) and trimethoprim (TMP). Bromo-thymolblue (BTB) nutrient agar (nutrient agar containing
$0.0045 \%$ BTB and $1 \%$ lactose) was used for the detection of transferable $\mathbf{R}$ plasmids.

Chemotherapeutics were used in the selection media at the following concentrations (micrograms per milliliter): chloramphenicol (CP), 25; tetracycline (TC), 25; streptomycin (SM), 100; nalidixic acid (NA), 100; SA, 500; and rifampicin, 100. The $E$. coli strains harbouring $\mathbf{R}$ plasmid were routinely grown at $37^{\circ} \mathrm{C}$ in $\mathrm{L}$ broth $(5 \mathrm{~g}$ yeast extract, $10 \mathrm{~g}$ polypetone, $5 \mathrm{~g} \mathrm{NaCl}$ per liter), solidified when necessary with the addition of agar at $1.5 \%$.

Drug Susceptibility Test

Minimal inhibitory concentrations (MICs) of various chemotherapeutic agents against strains of $E$. tarda were determined by serial two-fold 
dilution as described by Aoki et al. ${ }^{5)}$. The chemotherapeutic agents were CP, TC, SM, kanamycin (KM), ampicillin (AMP), cefazollin (CEZ), NA, furazolidone (NF), SA, and TMP. Resistance to each of these chemotherapeutics was scored after the determination of the MIC as described previously. ${ }^{4)}$

\section{Plasmid DNA Procedures}

$\mathrm{R}$ plasmids were isolated by the alkaline lysis method, ${ }^{8)}$ followed by centrifugation in ethidium bromide-cesium chloride gradients. Restriction endonucleases HindIII and Pst I were purchased from the Takara and Nippon Gene Cos. Ltd. and used according to the assay conditions specified by the manufacturers. Restriction fragments were then resolved by $0.8 \%$ agarose gel electrophoresis, denatured, and transferred to nitrocellulose filters as in a previously described method. ${ }^{e)}$

Southern blotting hybridization ${ }^{1)}$ was performed by standard methods. Nick translated $0.5 \mu \mathrm{g}$ of pK4 DNA probe was labelled with [ $\alpha{ }^{32}$ P]dCTP (NEN Research Product: $3000 \mathrm{Ci}$ / mmol). ${ }^{9)}$ Hybridizations were performed at $37^{\circ} \mathrm{C}$ for $8 \mathrm{~h}$ in $50 \%$ formamide-hybridization- $10 \times$ Denhardt's solution. ${ }^{6)}$ After hybridization, the filter was washed with $3 \times$ SSC $(1 \times$ SSC is $0.15 \mathrm{M}$ $\mathrm{NaCl}$ and $0.015 \mathrm{M}$ Sodium citrate, $\mathrm{pH} 7.0$ ) and $2 \times$ SSC containing $0.1 \%$ SDS. Filters were then dried and exposed to Fuji X-ray film at $-70^{\circ} \mathrm{C}$.

\section{Results}

\section{Drug Resistance of E. tarda Strains}

The spectrum of MICs of the 10 chemotherapeutic agents against the 186 strains of $E$. tarda is shown in Figure 1. The strains were classified

Table 2. R plasmids from Edwardsiella tarda

\begin{tabular}{llll}
\hline \hline \multicolumn{1}{c}{$\begin{array}{c}\mathrm{R} \\
\text { plasmids }\end{array}$} & \multicolumn{1}{c}{$\begin{array}{c}\text { Resistance } \\
\text { marker }\end{array}$} & \multicolumn{2}{c}{ Isolated in } \\
\cline { 3 - 4 } & & \multicolumn{1}{c}{ Area } & Year \\
\hline pAC8333 & CP SA & Aichi & 1983 \\
pKG8410 & TC SA & Kagoshima & 1984 \\
pAC8323 & CP TC SA & Aichi & 1983 \\
pAC8408 & CP TC SA & Aichi & 1984 \\
pSZ8403 & CP TC SA & Shizuoka & 1984 \\
pTK8401 & CP TC SA & Tokushima & 1984 \\
pKG8401 & CP TC SA & Kagoshima & 1984 \\
pAC8436 & CP TC SM SA & Aichi & 1984 \\
pK4 & CP TC SA & Kagoshima & 1978 \\
\hline
\end{tabular}

Abbreviations: CP, chloramphenicol; TC, tetracycline; SM, streptomycin; SA, sulfamonomethoxine. into two apparently discrete groups, those sensitive and those resistant to $\mathrm{CP}, \mathrm{TC}, \mathrm{SM}, \mathrm{NA}, \mathrm{NF}$, and SA. Fifty-one strains of 186 strains showed resistance to $\mathrm{CP}, 55$ strains resistant to TC, only one strain resistant to $\mathrm{SM}, 111$ strains resistant to NA, 150 strains resistant to NF, and 53 strains

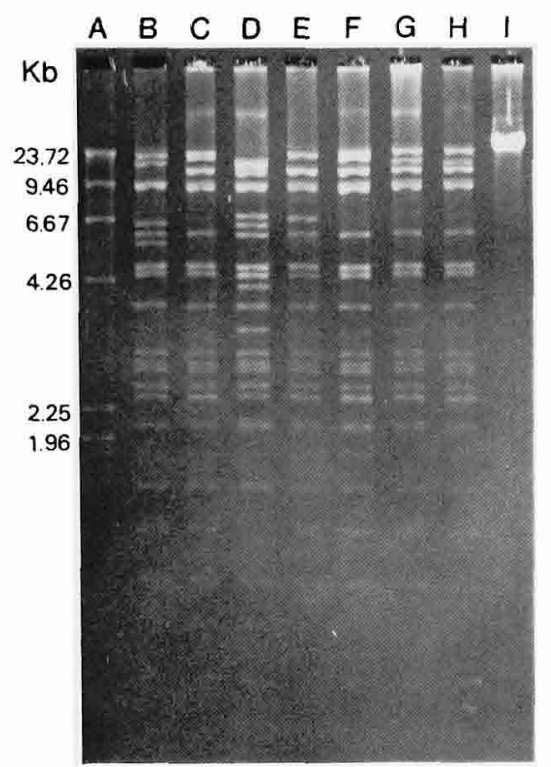

Fig. 2. HindIII digestion patterns of $\mathrm{R}$ plasmid DNAs isolated from Edwardsiella tarda.

Standard molecular size of 2 DNA (lane A) was digested by HindIII. Lane B, pAC8333; lane C, pKG8410; lane D, pAC8323; lane E, pAC8408; lane $\mathrm{F}$, pSZ8403, lane $\mathrm{G}$, pTK 8401 ; lane $\mathrm{H}$, pKG8401 and lane I, pAC8436.

Table 3. Resistance markers and transferable $R$ plasmids of Edwardsiella tarda

\begin{tabular}{lcl}
\hline $\begin{array}{c}\text { Resistance marker } \\
\text { of original strain }\end{array}$ & $\begin{array}{c}\mathrm{R}^{+} \text {strains/ } \\
\text { Strains } \\
\text { studied }\end{array}$ & $\begin{array}{c}\text { Resistance marker } \\
\text { of R plasmid }\end{array}$ \\
\hline Sensitive strains & $34^{*}$ & \\
NA & $0 / 2$ & \\
NF & $0 / 10$ & \\
NA NF & $0 / 84$ & \\
TC NF SA & $1 / 3$ & TC SA \\
CP TC NA NF & $0 / 3$ & \\
CP TC NF SA & $20 / 28$ & TC SA (1) \\
& & CP TC SA (19) \\
CP NA NF SA & $1 / 1$ & CP SA \\
TC NA NF SA & $0 / 2$ & \\
CP TC SM NA SA & $1 / 1$ & CP TC SM SA \\
CP TC NA NF SA & $8 / 18$ & CP TC SA \\
Total & $31 / 186$ & \\
\hline
\end{tabular}

* Number of strains. Abbreviations: CP, chloramphenicol; TC, tetracycline; SM, streptomycin; NA nalidixic acid; NF, furazolidone; $\mathrm{SA}$, sulfamonomethoxine. 
PANEL1 PANEL 2

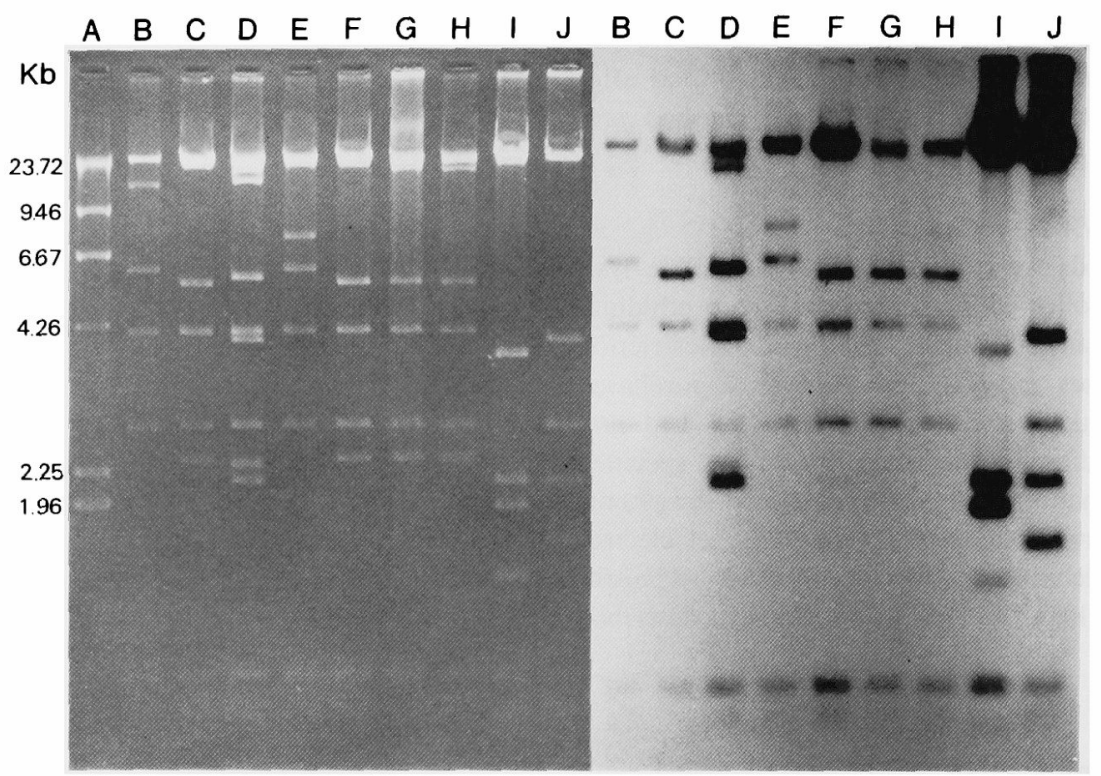

Fig. 3. Pst I digestion patterns of R plasmid DNAs from Edwardsiella tarda, and hybridization of ${ }^{32}$ P-labeled pK4 DNA.

Panel 1 is an agarose gel electrophoretic profiles of R plasmid DNAs digested by $P$ st I. Panel 2 is an autoradiogram of a nitrocellulose filter blotted with the DNA from Panel 1 and probed with ${ }^{32} \mathrm{P}$-labeled $\mathrm{pK} 4$. Standard molecular size $\lambda$ DNA (lane A) was digested by HindIII. Lane B, pAC8333; lane C, pKG8410; lane D, pAC8323; lane E, pAC8408; lane F, pSZ8403, lane G, pTK8401; lane H, pKG8401; lane I, pAC8436; and lane J, pK4.

resistant to SA.

Only 34 strains were found to be sensitive to all the drugs tested (Table 3), while the remaining 152 strains were resistant to combinations of $\mathrm{CP}$, TC, SM, NA, NF, and/or SA. In particular, 84 strains encoded with resistance to NA and NF were detected at high frequency.

\section{$R$ Plasmids from E. tarda}

Transferable $\mathbf{R}$ plasmids were detected in 31 of the 152 drug-resistant strains (Table 3). The $\mathrm{R}$ plasmids had various resistance markers to combinations of CP, TC, SM, and/or SA. R plasmids encoded with resistance to $\mathrm{CP}, \mathrm{TC}$, and $\mathrm{SA}$ were predominant. Seven of eight $\mathrm{R}$ plasmids from E. tarda, had identical HindIII digestion pattern (Fig. 2). The exception was pAC8436 which yielded 18 to 20 fragments. Common fragments with the same molecular sizes: 9.0, 5.5, 4.3, 4.1, 3.5 and/or 2.2 kilobase $(\mathrm{Kb})$ were observed in the HindIII digestion pattern for seven $\mathrm{R}$ plasmids encoded with different resistance markers.

With the exception of pAC8436 the digestion patterns with PstI was found to be identical to that of pK4 (Fig. 3). The fragments with molecular sizes of 4.2 and $2.6 \mathrm{~Kb}$ were found in seven $\mathrm{R}$ plasmids and pK4 but not in pAC8436. By Southern blot hybridization, ${ }^{1)} \mathrm{pK} 4$ showed high homology to each R plasmid detected in 1983 and 1984. The structure of the $\mathrm{R}$ plasmid detected in 1983 and 1984 was similar to that of the $R$ plasmids in 1978.2)

\section{Discussion}

It has been noted that wide or excessive use of chemotherapeutic agents for treatment of bacterial fish diseases is correlated with increasing drug resistant strains in eel culture ponds. The multiple drug-resistant strains of E. tarda distributed widely in eel culture ponds in the 1980's are the same as those in the 1970's. ${ }^{2,4)}$ In particular, nalidixic acid and nitrofuran resistant strains were detected in significant numbers among $E$. tarda in 1983 and 1984. Pyridonecarboxylic acid containing nalidixic acid was widely used for treatment of edwardsiellosis in eel culture ponds. 
The increase in NA resistant strains could parallel the extensive use of pyridonecarboxylic acid in eel culture ponds. However, nitrofuran derivatives has been restricted for use against bacterial infection of cultured eel in Japan since 1983. We can not explain the incidence of NF resistant strains in eel culture ponds.

The most prevalent drug resistance marker for the $R$ plasmids detected in 1983 and 1984 was shown to be CP, TC, and SA. The R plasmids encoding for resistance to TC and SA were detected from only two strains. However, R plasmids for TC and SA or CP, TC, and SA resistance were detected frequently from $E$. tarda strains in the 1970's." We demonstrated that the DNA structure of the $R$ plasmid with resistance to $C P, T C$, and $S A$ was identical with that of $R$ plasmid with resistance to TC and SA. ${ }^{2)}$ The $R$ plasmids with resistance to $\mathrm{CP}, \mathrm{TC}$, and SA constructed an additional $\mathrm{CP}$ resistant gene in the $\mathrm{R}$ plasmid for resistance to TC and SA. The $R$ plasmids detected in 1983 and 1984 had similar HindIII or Pst I digestion patterns with the exception of pAC8436 which encoded for CP, TC, SM, and SA resistance. However, the $\mathrm{R}$ plasmids in pAC8436 detected in the 1980's showed to have high homology with pK4 which was a typical R plasmid from E. tarda strain detected in the 1970's. That is to say, the DNA structure of R plasmids detected in 1983 and 1984 were identical to those of R plasmids in the 1970's. The $\mathrm{R}$ plasmids from $E$. tarda have diverged from a common ancestral DNA element since they are related with respect to incompatibility group ${ }^{3,10)}$ and resistance to drugs as well as base sequence homology.

Consequently, $E$. tarda strains carrying $\mathrm{R}$ plasmids with identical DNA structure prevailed in eel culture ponds in various areas in 1983 and 1984.

\section{References}

1) E. Southern: J. Mol. Biol., 98, 503-517 (1975).

2) T. Aoki, A. Akashi, and T. Sakaguchi: Nippon Suisan Gakkaishi, 52, 1173-1179 (1986).

3) T. Aoki, T. Arai, and S. Egusa: Microbiol. Immunol., 21, 77-83 (1977).

4) T. Aoki, and T. Kitao: Fish Pathol., 15, 277281 (1981).

5) T. Aoki, T. Kitao, T. Watanabe, and S. Takeshita: Microbiol. Immunol., 28, 1-9 (1984).

6) T. Maniatis, E. F. Fritsch, and J. Sambrook: in Molecular Cloning: A Laboratory Manual. Cold Spring Harbor Laboratory. Cold Spring Harbor, New York, 1982.

7) T. Watanabe, T. Aoki, Y. Ogata, and S. Egusa: Ann. New York Acad. Sci., 182, 383-410 (1971).

8) J. B. Hansen, and R.H. Olsen: J. Bacteriol., 135, 227-238 (1978).

9) P. Rigby, M. Dieckmann, C. Rhodes, and P. Berg: J. Mol. Biol., 113, 237-251 (1977).

10) T. Aoki, T. Kitao, and T. Arai: in "Plasmids Medical and Theoretical Aspects" (ed. by S. Mitsuhashi, S. Rosival and V. Krčméry), Avicenum, Czechoslvak Medical Press, Prague, 1977, pp. 39-45. 